\title{
ANALISIS KESESUAIAN LAHAN UNTUK PERMUKIMAN TRANSMIGRASI DI PULAU ENGGANO KABUPATEN BENGKULU UTARA
}

\author{
Deddy Fitrianto ${ }^{1)}$, Gunggung Senoaji ${ }^{2)}$, Satria Putra Utama ${ }^{3)}$ \\ $\left.{ }^{1}\right)$ Dinas Ketenagakerjaan dan Transmigrasi Prov. Bengkulu \\ 2) Jurusan Kehutanan Fakultas Pertanian Universitas Bengkulu. \\ ${ }^{3}$ ) Jurusan Agribisnis Fakultas Pertanian Universitas Bengkulu.
}

\begin{abstract}
ABSTRAK
Pembangunan Kawasan Enggano dimaksudkan untuk mengoptimalkan sumberdaya alam dan potensi strategis wilayah lainnya. Untuk mendukung pembangunan tersebut maka diusulkanlah pembangunan bidang-bidang yang berpengaruh terhadap perkembangan wilayah. Bidang-bidang tersebut adalah perencanaan wilayah, pembangunan perumahan dan permukiman, pemberdayaan ekonomi masyarakat dan peningkatan kualitas kelembagaan. Namun saat ini telah dirasakan kesulitan untuk memperoleh lahan yang memadai dan kesesuaiannya untuk permukiman transmigrasi. Selain karena kebutuhan lahan yang meningkat seiring dengan perkembangan penduduk dan ekonomi lokal, juga disebabkan oleh semakin terbatasnya ketersediaan lahan dengan kualifikasi layak huni. Penelitian ini bertujuan untuk mengetahuifaktor-faktor fisik yang mempengaruhi kesesuaian lahan untuk lahan transmigrasi di UPT Malakoni Pulau Enggano, dan juga mengetahui kesesuaian lahan pemukiman transmigrasi di UPT Malakoni Pulau Enggano. Metode data yang digunakan dalam penelitian ini meliputi teknik perbandingan (matching) dan metode tumpang susun peta (overlay).Dengan menggunakan bantuan perangkat lunak Sistem Informasi Geograis (SIG) Arc GIS 10.1, semua variabel di overlay, sehingga menghasilkan peta kesesuaian lahan untuk permukiman. Hasil analisis menunjukkan bahwa pada permukiman transmigrasi Desa Malakoni di Pulau Enggano didominasi oleh jarak dari pantai > 200 m, dengan ketinggian tempat > $15 \mathrm{~m} / \mathrm{dpl}$, kemiringan lahan agak curam (>15\%), sebagian besar kawasan permukiman tidak tergenang dan kedalaman efektif tanahnya dangkal. Tidak semua lahan permukiman transmigrasi Desa Malakoni sesuai untuk permukiman. Lokasi permukiman yang sesuai (S2) seluas 279 Ha (19,41\%), kawasan kurang sesuai seluas 510,7 Ha $(35,54 \%)$ dan kawasan yang tidak sesuai (S3)seluas 647,4 Ha (45,05\%).
\end{abstract}

Kata Kunci : kesesuaian lahan, permukiman, transmigrasi

\section{PENDAHULUAN}

Transmigrasi merupakan salah satu upaya pemerintah dalam mencapai keseimbangan penyebaran penduduk, memperluas kesempatan kerja, meningkatkan produksi dan meningkatkan pendapatan. Pemerintah berusaha mengatasi penyebaran penduduk yang tidak merata dengan meningkatkan program pembangunan di daerah sehingga penduduk menjadi tidak tertarik untuk tinggal di Pulau Jawa, atau dengan memindahkan sebagian penduduk di Pulau Jawa ke pulau-pulau yang lain yang tidak padat penduduknya seperti Sumatera, Kalimantan, Sulawesi dan Papua.

Pembangunan Kawasan Enggano dimaksudkan untuk mengoptimalkan sumberdaya alam dan potensi strategis wilayah lainnya. Untuk mendukung pembangunan tersebut maka diusulkanlah pembangunan bidang-bidang yang berpengaruh terhadap perkembangan wilayah. Bidang-bidang tersebut adalah perencanaan wilayah, pembangunan 
perumahan dan permukiman, pemberdayaan ekonomi masyarakat dan peningkatan kualitas kelembagaan.

Pelaksanaan program transmigrasi secara aspek legal dengan pertimbangan lingkungan telah dimasukkan pada pasal 2 Undang Undang Nomor 15 Tahun 1997 tentang Ketransmigrasian yang menyebutkan bahwa Wawasan Lingkungan merupakan salah satu dari 7 (tujuh) azas penyelenggaraan transmigrasi. Dalam tahap perencanaan transmigrasi aspek lingkungan telah dipertimbangkan, seperti menggunakan areal hutan yang berstatus hutan yang dapat dikonversi, rekomendasi penggunaan lahan yang sesuai dengan kemampuan tanahnya, pembatas kelerengan, dan pertimbangan aspek hidrologi. Sedangkan pada tahap pelaksanaan, pertimbangan aspek lingkungan telah dimasukan dalam teknis pelaksanaan yaitu pengamanan jalur disepanjang kiri-kanan sungai,pembukaan lahan tanpa bakar, pembukaan lahan secara manual dan/atau secara semi mekanis, pembangunan bendali, konservasi tanah dan air dengan memanfaatkan bahan organik.

Pada awalnya penyelenggaraan transmigrasi tidak sulit untuk menyediakan ruang dan menentukan lokasi transmigrasi di luar Pulau Jawa, karena lahan yang tersedia masih sangat luas. Namun saat ini telah dirasakan kesulitan untuk memperoleh lahan yang memadai dan kesesuaiannya untuk permukiman transmigrasi. Selain karena kebutuhan lahan yang meningkat seiring dengan perkembangan penduduk dan ekonomi lokal, juga disebabkan oleh semakin terbatasnya ketersediaan lahan dengan kualifikasi layak huni.

Tujuan dilakukan penelitian ini adalah : 1). Untuk mengetahuifaktor-faktor fisik yang mempengaruhi kesesuaian lahan untuk lahan transmigrasi di UPT Malakoni Pulau Enggano, 2). Untuk mengetahui kesesuaian lahan pemukiman transmigrasi di UPT Malakoni Pulau Enggano.

\section{METODE PENELITIAN}

\section{Waktu dan Tempat Penelitian}

Penelitian ini dilaksanakan selama 3 (tiga) bulan, adapun lokasi penelitian adalah UPT Malakoni Kecamatan Enggano Kabupaten Bengkulu Utara dengan luas lahan 1437,12 Ha.Penelitian ini dilakukan mulai bulan Maret sampai dengan bulan Mei 2018.

\begin{abstract}
Alat dan Bahan
Peralatan dan bahan yang digunakan dalam penelitian ini meliputi peta lokasi penelitian, peta kedalaman tanah, peta ketinggian tempat, peta drainase, peta jarak garis pantai, peta kemiringan lahan, peta kesesuaian lahan pemukiman transmigrasi, altimeter, klinometer, GPS, meteran, kamera dan alat tulis.
\end{abstract}

\section{Metode Penelitian}

Teknik pengumpulan dan informasi dilakukan dengan metode :

1. Data Primer

Pengambilan data primer dilakukan secara langsung dan diambil hasilnya pada waktu tersebut, kemudian dilakukan perekaman koordinat dan ketinggian lokasi survey dengan menggunakan alat GPS.

2. Data sekunder

Pengumpulan data sekunder dilakukan untuk mendukung data yang dibutuhkan. Selain melalui observasi dan wawancara, pengumpulan data sekunder juga dilakukan dengan mengambil data dari instansi-instansi terkait diantaranya Dinas Pekerjaan Umum dan Penataan Ruang Provinsi Bengkulu, Badan Perencanaan Pembangunan Daerah (Bappeda) Provinsi Bengkulu, Dinas Tenaga Kerja dan Transmigrasi Provinsi Bengkulu dan sebagainya sesuai data yang dibutuhkan.

\section{Pelaksanaan Lapangan}

Pemetaan topografi dilokasi dilakukan untuk memperoleh informasi 
mengenai status lahan, kondisi land use eksisting dan kemiringan lahan/lereng. Pemetaan topografi akan menjadi dasar dalam pembuatan peta tematik lain, survei kemiringan lahan yang akan dilakukan menjadi dasar dalam pembuatan peta kesesuaian lahan, informasi status lahan dan kondisi land use eksisting akan menjadi masukan dalam penentuan kesesuaian permukiman.

Data iklim dan potensi sumber daya air untuk mengetahui kondisi iklim, ketersediaan sumber air (air minum dan air pertanian) dan resiko banjir. Penyelidikan sumber daya air dengan melihat semua sub wilayah aliran sungai yang akan mempengaruhi lokasi permukiman transmigrasi. Daerah bahaya banjir harus diperkirakan berdasarkan data luas sungai, perkiraan pengaliran, bentuk sungai dan informasi penduduk sekitar. Tersedianya potensi sumber air bersih yang paling diharapkan adalah sumur dangkal, tetapi air permukaan dan air hujan harus diperhatikan juga.

\section{Metode Analisis Data}

Metode data yang digunakan dalam penelitian ini meliputi teknik perbandingan (matching) dan metode tumpang susun peta (overlay), yang diuraikan sebagai berikut

(1) Metode perbandingan (matching).

Metode ini merupakan suatu cara menilai kesesuaian lahan dengan cara membandingkan variabel parameter kesesuaian lahan antara kondisi wilayah dengan kriteria yang telah ditentukan. Data parameter kondisi wilayah diperoleh dari data lapangan maupun data sekunder, sedangkan pedoman kriteria penentuan kelas kesesuaian lahan ditentukan.

(2) Metode tumpang susun (overlay) dengan menggunakan analisa SIG.

Metode ini merupakan sistem penanganan data dalam evaluasi kesesuaian lahan dengan cara digital yaitu dengan menggabungkan beberapa peta yang memuat informasi yang disyaratkan untuk suatu program dengan karakteristik lahannya.

Teknik yang digunakan dalam analisis ini adalah teknik overlay dengan memasukan beberapa variabel yang telah didapat. Dalam penelitian ini peta yang dibutuhkan adalah peta kemiringan lahan, peta jarak dari pantai, peta drainase, peta ketinggian dan peta kedalaman efektifitas tanah.Dengan menggunakan bantuan perangkat lunak Sistem Informasi Geograis (SIG) Arc GIS 10.1, semua variabel di overlay, sehingga menghasilkan peta kesesuaian lahan untuk permukiman.

\section{Analisis Data}

\section{Analisis Kesesuaian Lahan}

Perbandingan lokasi permukiman transmigrasi di Desa Malakoni akan menggunakan peta kedalaman tanah, peta ketinggian tempat, peta drainase, peta jarak garis pantai dan peta kemiringan lahan di Kecamatan Enggano.

\section{Variabel yang diamati}

Variabel yang digunakan untuk menentukan kesesuaian lahan permukiman pada lokasi transmigrasi di Desa Malakoni dapat dilihat pada Tabel 1. 
P-ISSN: 2302- 6715

E- ISSN: 2654-7732

Tabel.1. Variabel Kesesuaian Lahan Permukiman

\begin{tabular}{lll}
\hline \multicolumn{1}{c}{ Variabel } & \multicolumn{1}{c}{ Indikator } & \multicolumn{1}{c}{ Kelas Kesesuaian Lahan } \\
\hline Kemiringan Lahan $(\%)$ & $0-3$ & S1 (Sangat Sesuai) \\
& $4-8$ & S2 (Sesuai) \\
& $9-15$ & S3 (Kurang Sesuai) \\
Jarak dari Pantai $(\mathrm{m})$ & $>15$ & N (Tidak Sesuai) \\
& $>200$ & S1 (Sangat Sesuai) \\
& $100-200$ & S2 (Sesuai) \\
Ketinggian (m/dpl) & $5-100$ & S3 (Kurang Sesuai) \\
& $0-5$ & N (Tidak Sesuai) \\
& $>15$ & S1 (Sangat Sesuai) \\
Drainase & $5-15$ & S2 (Sesuai) \\
& $<5$ & S3 (Kurang Sesuai) \\
& Tidak Pernah Tergenang & S1 (Sangat Sesuai) \\
& Tidak Tergenang & S2 (Sesuai) \\
& Tergenang Periodik & S3 (Kurang Sesuai) \\
Kedalaman Efektif Tanah & Tergenang $/$ Rawa & N (Tidak Sesuai) \\
& Dalam $(>90 \mathrm{~cm})$ & S1 (Sangat Sesuai) \\
& Sedang $(60-90 \mathrm{~cm})$ & S2 (Sesuai) \\
& Dangkal $(30-60 \mathrm{~cm})$ & S3 (Kurang Sesuai) \\
& Sangat dangkal $(<30 \mathrm{~cm})$ & N (Tidak Sesuai) \\
\hline
\end{tabular}

\section{HASIL DAN PEMBAHASAN}

\section{Gambaran Umum Kondisi Pulau Enggano Kabupaten Bengkulu Utara}

Pulau Enggano merupakan suatu kawasan pulau-pulau kecil terluar dengan luas wilayahnya \pm 40.060 ha, secara geografis terletak di perairan Samudera Hindia dengan jumlah penduduk 3.995 jiwa (Data Kecamatan Enggano Tahun 2018) dan secara administrasi merupakan bagian wilayah Kabupaten Bengkulu Utara.

\section{Kondisi Wilayah Penelitian di Desa Malakoni}

Desa Malakoni masuk dalam salah satu wilayah di Kecamatan Enggano dengan luas wilayah \pm 4.021 ha, dengan jumlah penduduk 281 jiwa (Kecamatan Enggano dalam Angka,2014). Areal lokasi transmigrasi Malakoni secara administrasi termasuk dalam wilayah Desa Malakoni Kecamatan Enggano, Kabupaten Bengkulu Utara, Provinsi Bengkulu.
Batas-batas wilayah Desa Malakoni secara fisik yaitu sebelah utara berbatasan dengan Jalan Provinsi (ruas Kahyapu Malakoni), sebelah selatan berbatasan dengan HPT Hulu Malakoni, sebelah timur berbatasan dengan Air Beuwa dan Eks UPT Kaana dan sebelah barat berbatasan dengan Sungai Kuala Besar, dan rincian ini

\section{Analisis Variabel Jarak dariPantai}

Pada daerah pinggiran pantai dengan jarak tertentu, oleh masyarakat nelayan banyak digunakan dengan pertimbangan kemudahan aksesibilitas ke laut untuk mencari ikan. Namun secara ekologis daerah ini berperan untuk mendukung fungsi pantai dan juga sebagai penyangga bila terjadi limpasan air laut adanya intrusi air laut. Sehingga daerah pantai lebih baik diperuntukan sebagai kawasan lindung. Adapun peta jarak dari pantai pada lokasi penelitian ini dapat dilihat pada Gambar 1. 


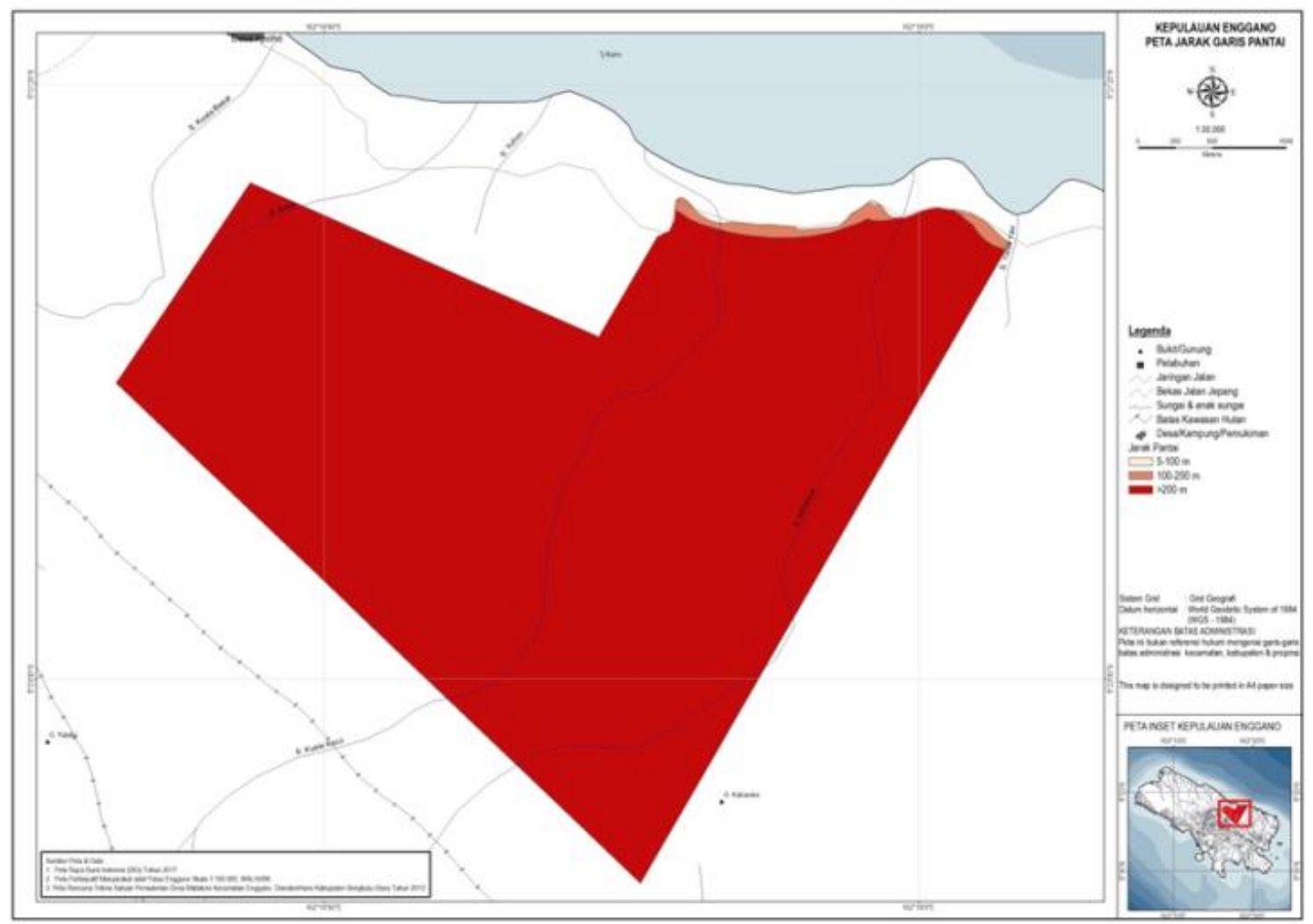

Gambar 1. Peta Jarak dari Pantai Desa Malakoni

Pada wilayah penelitian, jarak dari pantai didominasi oleh jarak >200 m dengan luas 1424,4 Ha. Selanjutnya untuk jarak 100-200 m memiliki luas 12,6 Ha dan yang terkecil adalah pada jarak 5-100 m dengan luas $0,1 \mathrm{Ha}$. Hasil penelitian ini dapat dilihat pada Tabel 2 .

Tabel 2. Hasil analisis untuk variabel jarak dari pantai

\begin{tabular}{|c|c|c|c|}
\hline Jarak dari Pantai & Luas $(\mathrm{Ha})$ & $\%$ & Kelas Kesesuaian Lahan \\
\hline$>200 \mathrm{~m}$ & 1424.4 & 99.11 & S1 (Sangat Sesuai) \\
\hline $100-200 \mathrm{~m}$ & 12.6 & 0.88 & S2 (Sesuai) \\
\hline $5-100 m$ & 0.1 & 0.01 & S3 (Kurang Sesuai) \\
\hline $0-5 \mathrm{~m}$ & - & - & N (Tidak Sesuai) \\
\hline Jumlah & 1437.1 & 100 & \\
\hline
\end{tabular}

Merujuk pada kesesuaian lahan untuk permukiman jarak yang ideal untuk permukiman adalah $>100 \mathrm{~m}$ dari tepi pantai. Jarak ini diasumsikan sebagai jarak yang aman bila terjadi bencana banjir. Kondisi lahan daratan yang ada di daerah penelitian yang berjarak $>200 \mathrm{~m}$ dari tepi pantai mencakup lahan yang sangat luas yaitu seluas $1424,4 \mathrm{Ha}(99,12 \%)$ dan untuk jarak 100-200 $\mathrm{m}$ seluas $12,6 \mathrm{Ha}$ $(0,88 \%)$. Sementara daerah yang jaraknya 5-100 m hanya seluas $0,1 \mathrm{Ha}(0,01 \%)$. Ini berarti bahwa sebagian besar lahan di daerah penelitian ini layak untuk dijadikan kawasan permukiman. 


\section{Analisis Variabel Ketinggian Tempat}

Secara umum permukiman transmigrasi Malakoni berada pada 15 meter diatas permukaan air laut. Dengan demikian dari segi geografis permukiman transmigrasi Malakoni termasuk zona dataran rendah (kurang dari 100 meter dibawah permukaan air laut). Untuk lebih jelasnya dapat dilihat pada Gambar 2.

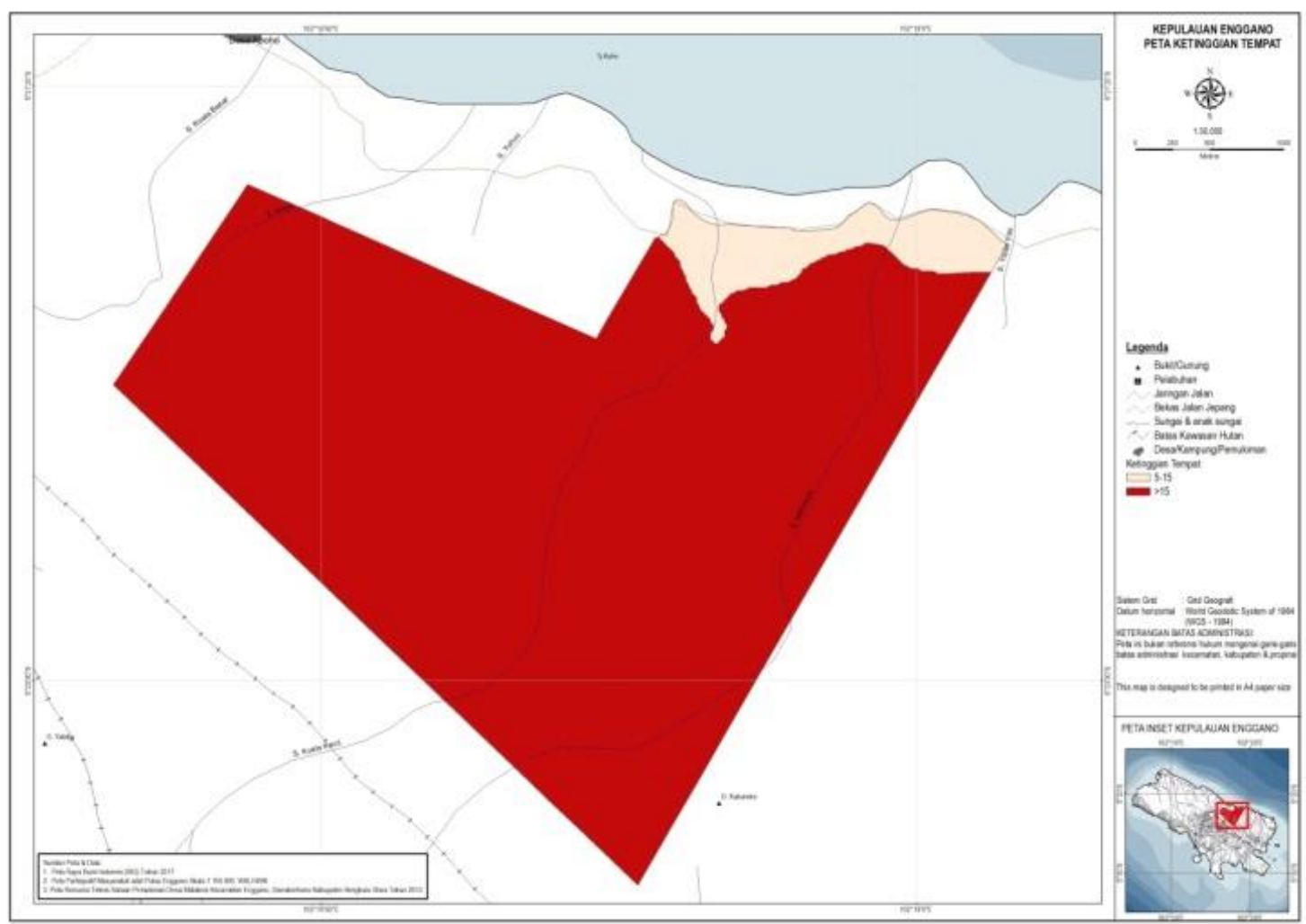

Gambar 2. Peta Ketinggian Tempat Desa Malakoni

Berdasarkan hasil analisis diketahui bahwa ketinggian tempat didaerah penelitian didominasi oleh ketinggian $>15$ m/dpl dengan luas 1355,5 Ha (94,32\%), sedangkan yang terkecil adalah seluas 81,6 Ha $(5,68 \%)$. Hasil analisis ini dapat dilihat pada Tabel 3.

Tabel 3. Hasil Analisis untuk Variabel Ketinggian

\begin{tabular}{|c|c|c|c|}
\hline Ketinggian & Luas (Ha) & $\%$ & Kelas Kesesuaian Lahan \\
\hline$>15 \mathrm{~m} / \mathrm{dpl}$ & 1355.5 & 94.32 & S1 (Sangat Sesuai) \\
\hline $5-15 \mathrm{~m} / \mathrm{dpl}$ & 81.6 & 5.68 & S2 (Sesuai) \\
\hline$<5 \mathrm{~m} / \mathrm{dpl}$ & - & - & S3 (Kurang Sesuai) \\
\hline Jumlah & 1437.1 & 100 & \\
\hline
\end{tabular}

Berdasarkan The urban, rulal regional planning field (1980) bahwa kegiatan budidaya perkotaan dapat dikembangkan pada ketinggian regional < $1.000 \mathrm{~m} / \mathrm{dpl}$. Berdasarkan kriteria ketinggian tersebut, maka wilayahMalakoni sangat sesuai untuk pengembangan kawasan permukiman transmigrasi. 


\section{Analisis Variabel Kemiringan Lahan}

Kemiringan lahan merupakan dasar dalam pembuatan peta kesesuaian lahan, informasi status lahan dan kondisi land use akan dijadikan masukkan dalam analisis tata ruang untuk penentuan kesesuaian permukiman. Deskripsi terhadap kemiringan lahan pada wilayah permukiman Desa Malakoni Kecamatan Enggano dapat dilihat pada Gambar 3.

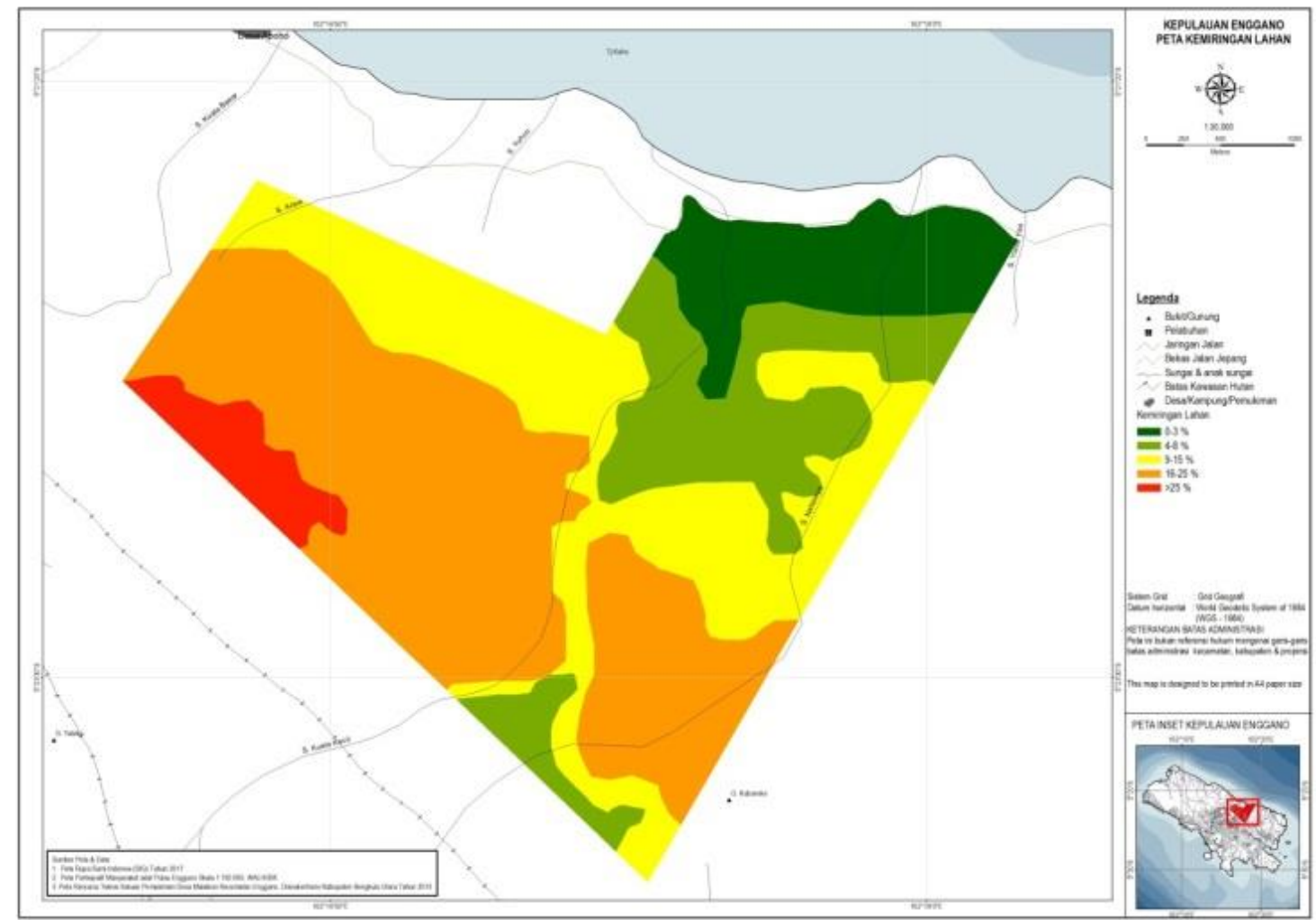

Gambar 3. Peta Kemiringan Lahan Desa Malakoni

Berdasarkan hasil analisis diketahui bahwa penelitian terhadap bentuk wilayah areal lokasi permukiman transmigrasi
Malakoni didominasi oleh kemiringan $>15$ $\%$. Selanjutnya kemiringan lahan Desa Malakonidapat dilihat pada Tabel. 4.

Tabel 4. Hasil analisis untuk variabel kemiringan lahan

\begin{tabular}{lccll}
\hline Kemiringan Lahan & $\begin{array}{c}\text { Luas } \\
(\mathrm{Ha})\end{array}$ & $\%$ & Kelas Kesesuaian Lahan \\
\hline $0-3 \%$ & 157.4 & 10.95 & S1 (Sangat Sesuai) \\
$4-8 \%$ & 235.2 & 16.37 & S2 (Sesuai) \\
$9-15 \%$ & 397.1 & 27.63 & S3 (Kurang Sesuai) \\
$>15 \%$ & & 647.4 & 45.05 & N (Tidak Sesuai) \\
\hline & & 1437.1 & 100 & \\
\hline
\end{tabular}

Berdasarkan Tabel 4 diketahui bahwa kemiringan lahan di Desa Malakoni didominasi kelas kemiringan lahan agak curam (>15\%) dengan luas 647,4 Ha $(45,05 \%)$, diikuti kelas kemiringan lahan landai (9-15\%) dengan luas 397,1 Ha $(27,63 \%)$, kemudian kelas kemiringan lahan agak datar (4-8\%) dan datar (0-3\%) dengan luas masing-masing 235,2 $\mathrm{Ha}$ $(16,37 \%)$ dan $157,4 \mathrm{Ha}(10,05 \%)$. 
Daerah yang reliefnya cenderung datar, sangat baik digunakan untuk lokasi pembangunan permukiman. Hal tersebut dikarenakan, daerah yang datar pembangunan rumahnya lebih mudah bila dibandingkan dengan daerah yang curam. Kemiringan lahan memiliki pengaruh yang lebih besar terhadap terjadinya erosi. Semakin besar kemiringan maka laju aliran permukaan semakin tinggi dan kemampuan tanah untuk meresapkan air semakin kecil, dan inilah yang menyebabkan daerah yang memiliki kemiringan tinggi kemungkinan besar potensi erosinya lebih besar.

\section{Analisis Variabel Drainase}

Sungai sungai yang berada terdapat dalam lokasi penelitian diantaranya adalah Sungai Kampak, Sungai Butun, Sungai Jerambah Panjang, Sungai Mukuh dan Sungai Malakoni. Dari kelima sungai tersebut diatas, maka Sungai Kampak, Sungai Jerambah Panjang dan Sungai Butun masih dipengaruhi oleh pasang surut air laut. Sedangkan Sungai Mukuh dan Sungai Malakoni masih dipengaruhi air gambut. Sehingga tidak disarankan untuk memenuhi kebutuhan air minum. Gambaran mengenai tingkat drainase yang ada di Desa Malakoni dapat dilihat pada Gambar 4.

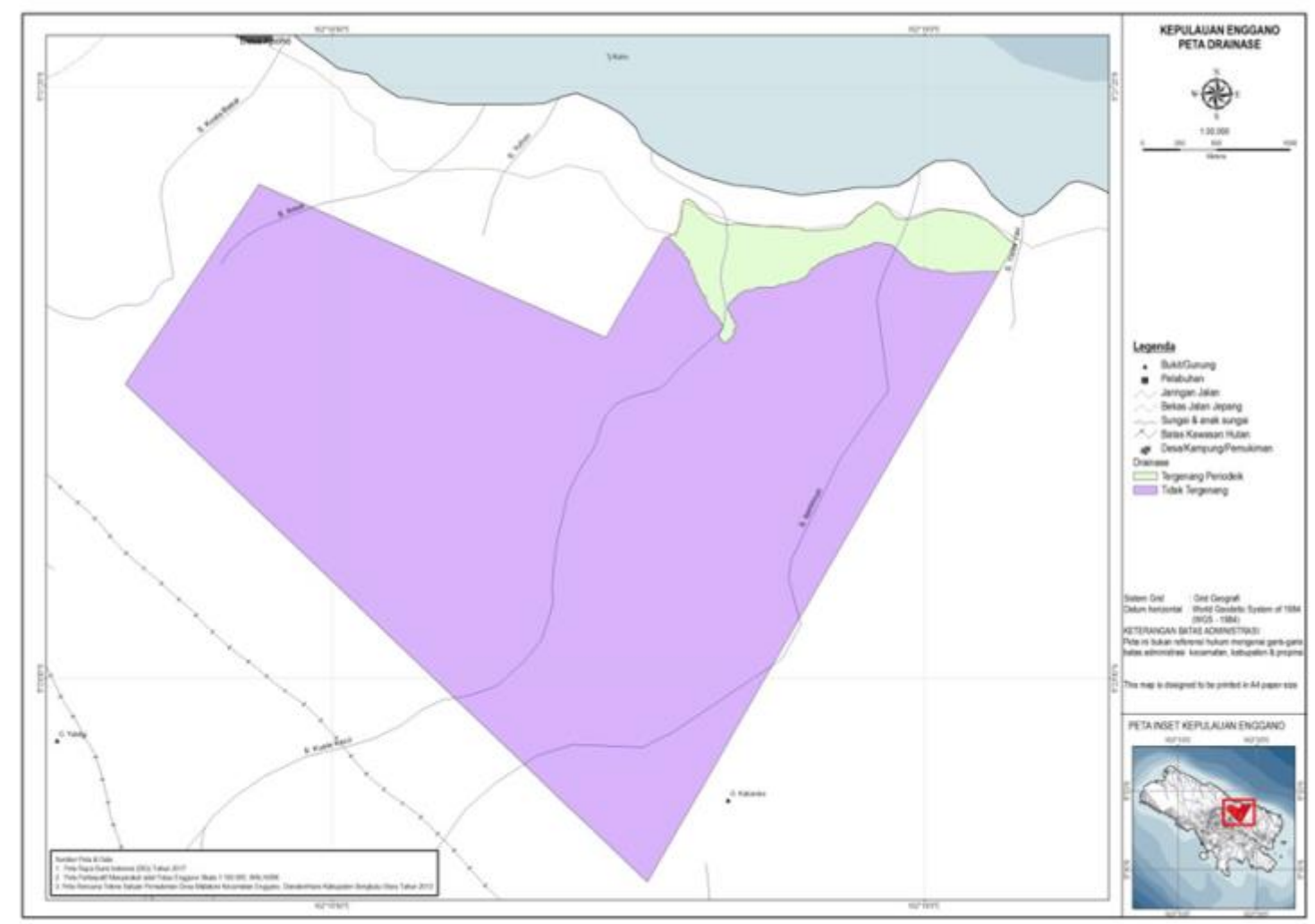

Gambar 4. Peta Drainase Desa Malakoni

Drainase di wilayah penelitian pada dasarnya merupakan kawasan yang agak berbukit sehingga jarang sekali terjadi genangan banjir yang disebabkan oleh hujan. Namun demikian tidak semua lahan terbebas dari banjir tersebut, terdapat 81,6
Ha $(5,68 \%)$ kawasan tergenang secara periodik, dan sebagian besar kawasan ini tidak tergenang yaitu seluas $1355,5 \mathrm{Ha}$ $(94,32 \%)$. Untuk lebih jelasnya dapat dilihat pada Tabel 5. 
Tabel 5. Hasil Analisis untuk Variabel Drainase

\begin{tabular}{lccl}
\hline \multicolumn{1}{c}{ Drainase } & $\begin{array}{c}\text { Luas } \\
(\mathrm{Ha})\end{array}$ & $\%$ & \multicolumn{1}{l}{ Kelas Kesesuaian Lahan } \\
\hline Tidak Pernah Tergenang & - & - & S1 (Sangat Sesuai) \\
Tidak Tergenang & 1355.5 & 94.32 & S2 (Sesuai) \\
Tergenang Periodik & 81.6 & 5.68 & S3 (Kurang Sesuai) \\
Tergenang/Rawa & - & - & N (Tidak Sesuai) \\
\hline \multicolumn{1}{c}{ Jumlah } & 1437.1 & 100 & \\
\hline
\end{tabular}

Erosi merupakan salah satu penyebab terjadinya kerusakan lahan dan timbulnya lahan kritis. Akibat erosi produktivitas lahan akan menurun, keadaan lingkungan menjadi rusak serta banjir di areal hilir meningkat. Erosi dipengaruhi oleh beberapa faktor yaitu iklim, tanah, topografi, penutup lahan dan kegiatan manusia. Erosi dalam kajian pembangunan permukiman berpengaruh pada kondisi tanah terhadap bangunannya.

Bahaya erosi yang dimaksud adalah hilangnya tanah dari lapisan atas secara maksimum. Secara kualitatif erosi ini merupakan hasil kerja antara faktor-faktor iklim, lereng dan perlakuan manusia. Erosi ini pada dasarnya dapat dicegah seminimal mungkin. Untuk itu tingkat bahaya erosi di lokasi penelitian yang umumnya memilki kondisi kemiringan lahan yang datar sampai agak berombak serta umumnya dalam kondisi tergenang kecuali pada areal yang sudah dibuatkan saluran drainase dapat sangat kecil, karena secara umum tingkat kemiringannya dapat dianggap datar.

\section{Analisis Variabel Kedalaman Efektif Tanah}

Kedalaman efektif tanah sangat mempengaruhi perkembangan akar tanaman, apabila kedalamannya relatif tipis maka akan menghambat perkembangan akar. Untuk melihat kedalaman efektif tanah di Desa Malakoni dapat dilihat pada Gambar 5.

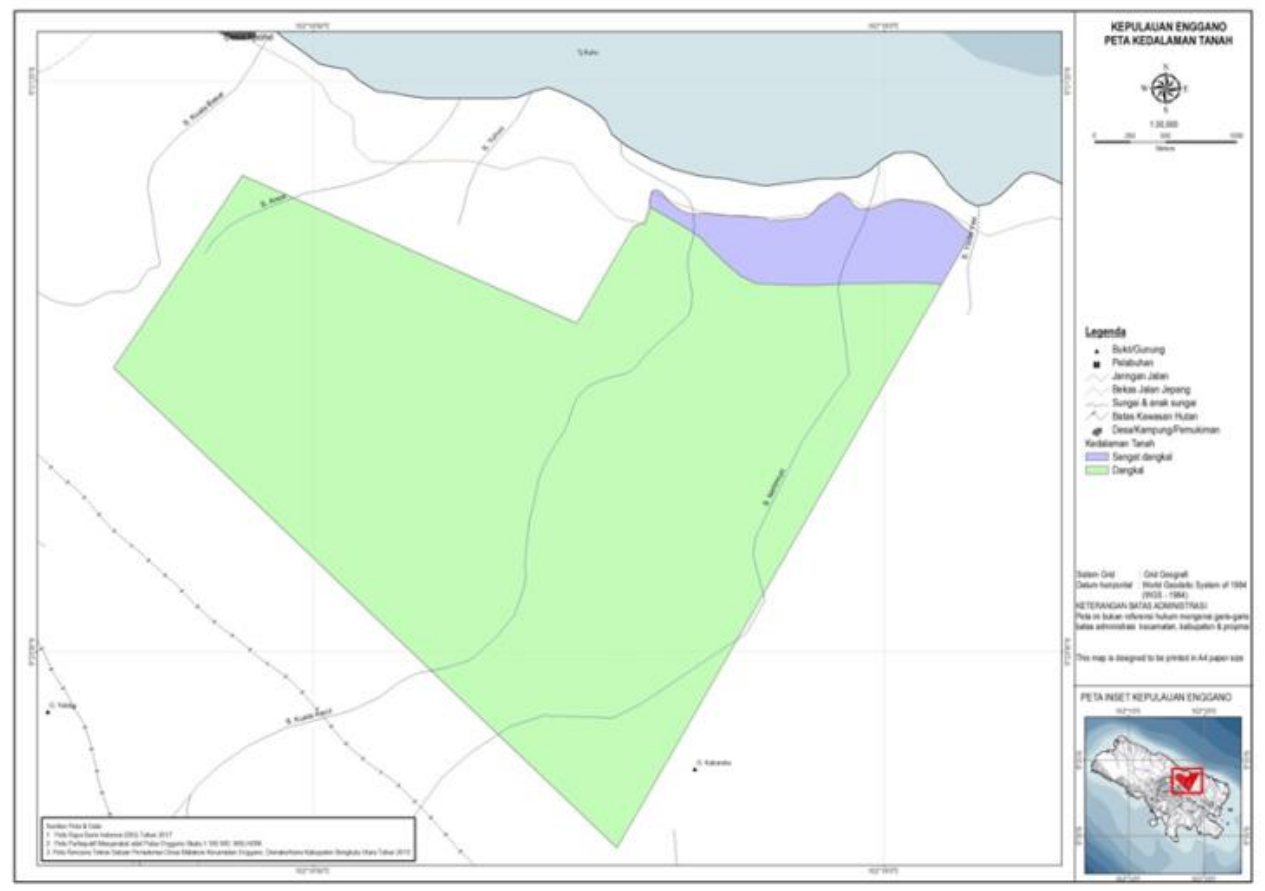

Gambar 5. Peta Kedalaman Efektif Tanah Desa Malakoni 
Kondisi kedalaman tanah di Desa Malakoni umumnya berada pada tanah yang dangkal, kondisi ini mencerminkan kondisi lahan yang dangkal dan kurang cukup baik bagi kesesuaian lahan permukiman. Hasil analisis ini dapat dilihat pada Tabel 6.

Tabel 6. Hasil Analisis untuk Variabel Kedalaman Efektif Tanah

\begin{tabular}{lccl}
\hline \multicolumn{1}{c}{ Kedalaman Efektif Tanah } & $\begin{array}{c}\text { Luas } \\
(\mathrm{Ha})\end{array}$ & $\%$ & \multicolumn{1}{l}{ Kelas Kesesuaian Lahan } \\
\hline Dalam $(>90 \mathrm{~cm})$ & - & - & S1 (Sangat Sesuai) \\
Sedang $(60-90 \mathrm{~cm})$ & - & - & S2 (Sesuai) \\
Dangkal $(30-60 \mathrm{~cm})$ & 1344.4 & 93.55 & S3 (Kurang Sesuai) \\
Sangat dangkal $(<30 \mathrm{~cm})$ & 92.7 & 6.45 & N (Tidak Sesuai) \\
\hline \multicolumn{1}{c}{ Jumlah } & 1437.1 & 100 & \\
\hline
\end{tabular}

Desa Malakoni seluas 1344,4 Ha $(93,55 \%)$ kedalaman tanahnya dangkal, sementara $92,7 \mathrm{Ha}(6,45 \%)$ berada pada kedalaman tanah sangat dangkal. Dari sebaran kedalaman efektif tanah yang disajikan pada Tabel 6 dapat diperkirakan bahwa lahan di Desa Malakoni kurang sesuai untuk permukiman bila ditinjau dari aspek kedalaman tanah. Pembangunan perumahan atau permukiman pada lahan semacam ini akan memerlukan konstruksi yang khusus seperti rumah panggung dan fondasi yang harus kuat.

\section{Kesesuaian Lahan Permukiman Transmigrasi}

Kesesuaian lahan merupakan tingkat kecocokan sebidang lahan untuk suatu tujuan penggunaan tertentu. Kesesuaian lahan suatu areal dapat berbeda-beda tergantung dari tipe penggunaan lahan (land utilization type) yang dikehendaki atau dipertimbangkan.

Penilaian kesesuaian lahan ini merupakan pemilahan atau penentuan bidang-bidang lahan yang mempunyai sifat-sifat positif dalam hubungannya dengan keberhasilan produksi sesuai dengan penggunaannya. Hal ini dilakukan dengan jalan menginterpretasikan sifatsifat satuan peta lahan dalam hubungannya dengan persyaratan dan kendala-kendala di dalam pengolahan bidang-bidang tersebut.

Wilayah yang termasuk dalam kesesuaian lahan dengan kategori sangat sesuai (S1) umumnya berada di wilayah dengan karakteristik yaitu kemiringan lahan 0-3\%, jarak dari pantai > $200 \mathrm{~m}$, ketinggian tempat $>15 \mathrm{~m} / \mathrm{dpl}$, drainase tidak pernah tergenang dan kedalaman efektif tanah $>75 \mathrm{~cm}$ (dalam). Untuk kategori cukup sesuai (S2) karateristiknya adalah kemiringan lahan 4-8\%, jarak dari pantai 100-200 m, ketinggian tempat 11-15 $\mathrm{m} / \mathrm{dpl}$, drainase tidak tergenang, dan kedalaman efektif tanah $50-75 \mathrm{~cm}$ (sedang). Pada kategori sesuai marginal (S3) memiliki karakteristik yaitu kemiringan lahan 9-15\%, jarak dari pantai 5-100 m, ketinggian tempat $5-10 \mathrm{~m} / \mathrm{dpl}$, drainase tergenang periodik dan kedalaman tanah efektif 20-50 cm (dangkal). Dan untuk kategori tidak sesuai pemanen (N) memiliki karakteristik kemiringan lahan > $15 \%$, jarak dari pantai $0-5 \mathrm{~m}$, ketinggian tempat $<5 \mathrm{~m} / \mathrm{dpl}$, drainase tergenang rawa, dan kedalaman efektif tanah $<20 \mathrm{~cm}$ (sangat dangkal).

Kesesuaian lahan untuk kawasan permukiman penduduk diperoleh dari analisis variabel-variabel kesesuaian lahan untuk kawasan ini, yang meliputi variabel kemiringan lahan, drainase, jarak dari pantai kedalaman efektif tanah dan ketinggian tempat. Semua variabel di overlay, sehingga menghasilkan peta kesesuaian lahan untuk permukiman transmigrasi Desa Malakoni. Penetapan arahan kesesuaian lahan dilakukan dengan menjumlahkan skor dari kelima variabel yang dinilai pada setiap satuan lahan. Jumlah skor tersebut akan mencerminkan 
kesesuaian lahan untuk masing-masing satuan lahan. Untuk melihat peta kesesuaian lahan ini dapat dilihat pada Gambar 6.

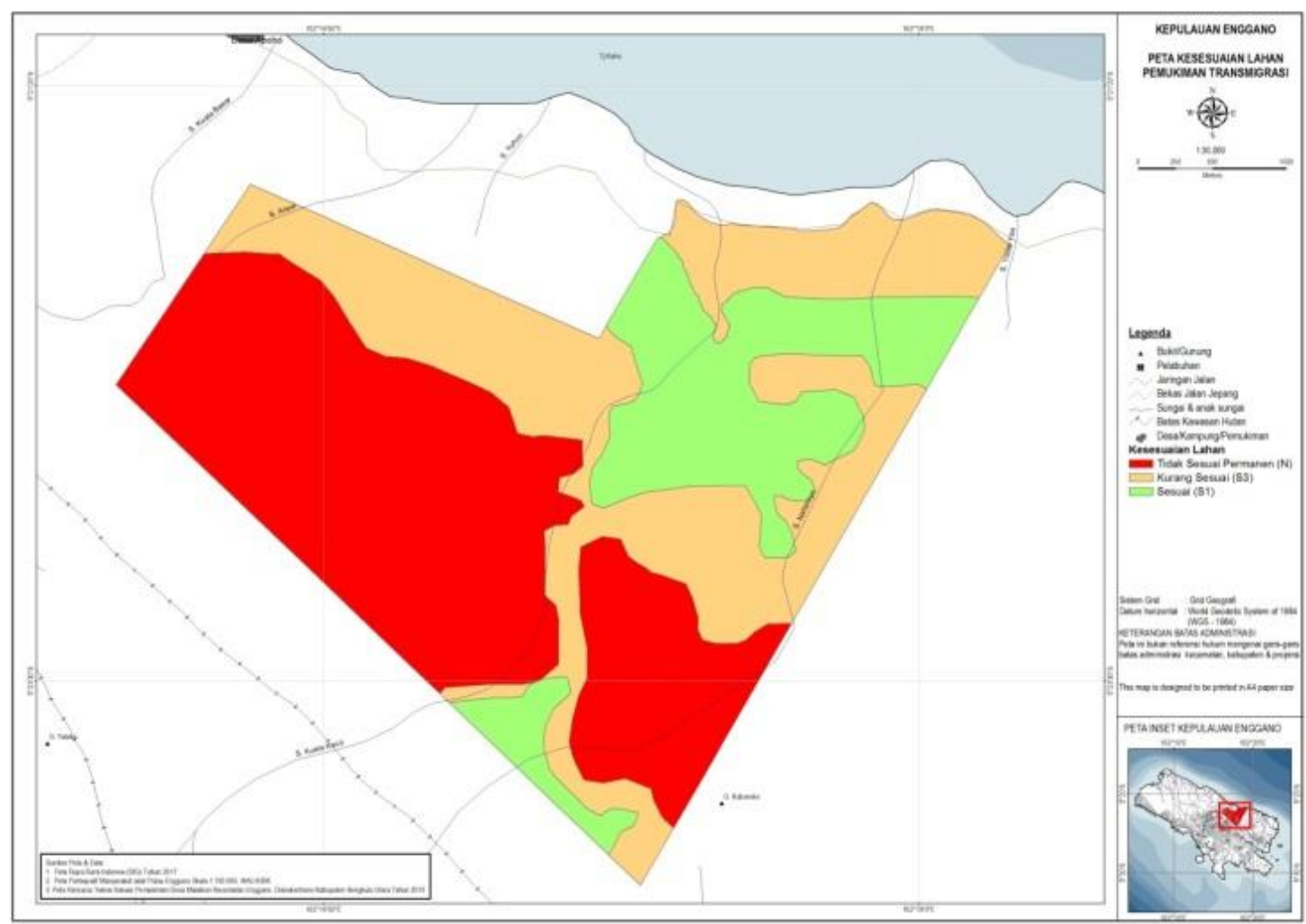

Gambar 6. Peta Kesesuaian Lahan Desa Malakoni

Hasil analisis kesesuaian lahan permukiman menunjukkan bahwa pada kategori tidak sesuai $(\mathrm{N})$ pada kesesuaian lahan permukiman mendominasi wilayah Desa Malakoni dengan luas 647,4 $\mathrm{Ha}$ $(45,05 \%)$, sedangkan wilayah seluas 510,7
Ha $(35,54 \%)$ merupakan kategori sesuai marginal (S3) dan wilayah seluas $279 \mathrm{Ha}$ $(19,41 \%)$ masuk wilayah cukup sesuai (S2). Hasil analisis kesesuaian lahan permukiman transmigrasi Desa Malakoni disajikan pada Tabel 7.

Tabel 7. Hasil analisis untuk variabel kesesuaian lahan permukiman

\begin{tabular}{lccc}
\hline & Tingkat Kesesuaian & Luas (Ha) & $\%$ \\
\hline Sangat Sesuai (S1) & & - & - \\
Sesuai (S2) & & 279 & 19.41 \\
Kurang Sesuai (S3) & & 510.7 & 35.54 \\
Tidak Sesuai (N) & Jumlah & 647.4 & 45.05 \\
\hline & & 1437.1 & 100 \\
\hline
\end{tabular}

Pertumbuhan penduduk dan ekonomi pada suatu wilayah akan mendorong peningkatan pemanfaatan lahan untuk kawasan permukiman, sebagai akibatnya banyak kawasan permukiman berkembang pada zona yang tidak sesuai dengan penggunaannya (Burhanuddin, 2010 dalam Umar, dkk, 2017). Penggunaan lahan yang tidak sesuai dengan 
penggunaannya dapat menimbulkan kerusakan lahan (Kumajas, 2006; Zakaria dan Hartono, et al, 2015 dalam Umar, $d k k, 2017)$. Penggunaan lahan yang tidak sesuai dengan penggunaannya tidak hanya berdampak pada kerusakan lahan, namun juga akan menimbulkan bencana alam dan degradasi lingkungan (Sumardikum, 2007, Rachmat et al, 2014 dalam Umar, $d k k, 2017)$.

\section{KESIMPULAN}

Berdasarkan hasil analisis yang telah dilakukan, maka dapat disimpulkan bahwa :

1. Pada permukiman transmigrasi Desa Malakoni di Pulau Enggano didominasi oleh jarak dari pantai > $200 \mathrm{~m}$, dengan ketinggian tempat > $15 \mathrm{~m} / \mathrm{dpl}$, kemiringan lahan agak curam $(>15 \%)$, sebagian besar kawasan permukiman tidak tergenangdan kedalaman efektif tanahnya dangkal.

2. Tidak semua lahan permukiman transmigrasi Desa Malakoni sesuai untuk permukiman. Lokasi permukiman yang sesuai (S2) seluas 279 Ha (19,41\%), kawasan kurang sesuai seluas 510,7 Ha $(35,54 \%)$ dan kawasan yang tidak sesuai (S3)seluas 647,4 Ha $(45,05 \%)$.

\section{DAFTAR PUSTAKA}

Andina, Pitra A., dan Taufik M. 2015. Evaluasi Kesesuaian Lahan Peruntukan Kawasan Permukiman, Industri, Mangove Wilayah Pesisir Utara Surabaya Tahun 2010 dan 2014. Jurnal Teknik Pomit. Vol. X No. X. Hal. 1-6.

Hamzah, S. 2013. Pendidikan Lingkungan : Sekelumit
Wawasan Pengantar. Refika Aditama. Bandung.

Lutfia, C. 2017. Kesesuaian Lahan unuk Pengembangan Kebun Kelapa Sawit Ramah Lingkungan di LingkunganKonsesi PT. Metatani Palma Abadi Kabupaten Seluma. Tesis. Fakultas Pertanian Program Studi Pascasarjana Pengelolaan Sumberdaya Alam dan Lingkungan. Universitas Bengkulu. Bengkulu (tidak dipublikasikan).

Muta'ali, L. 2013. Strategi Penyediaan Ruang untuk Transmigrasi Swakarsa Mandiri.Buku Transmigrasi : Solusi Permasalahan Bangsa. Hal. 247266.

Rachmawati, R. 2013. Strategi Pengembangan Wilayah Transmigrasi untuk Percepatan Pembangunan Daerah Tertinggal. Buku Transmigrasi : Solusi Permasalahan Bangsa. Hal. 187-191.

Salim, E. 1991. Pembangunan Berwawasan Lingkungan. Penerbit LP3ES. Jakarta.

Sari, Y A. 2013. Analisis Kesesuaian Lahan untuk Lokasi Permukiman Kecamatan Bantul Kabupaten Bantul. Skripsi. Fakultas Geografi Universitas Muhammadiyah Surakarta. Surakarta (tidak dipublikasikan).

Satria, M., dan Rahayu S. 2013. Evaluasi Kesesuaian Lahan Permukiman di Kota Semarang Bagian Selatan. Jurnal Teknik PWK. Volume 2 Nomor 1. Hal. 160-167.

Senoaji, G., dan Suminar R. 2006. Daya

Dukung Lingkungan Pulau Enggano Propinsi Bengkulu. Bapeldalda Propinsi Bengkulu. Bengkulu. 
P-ISSN: 2302- 6715

E-ISSN: 2654- 7732

Soemarwoto, O. 2004. Atur Diri

Sendiri : Paradigma Baru Pengelolaan Lingkungan Hidup. Gadjah Mada University Press. Yogyakarta.

Sulistyo, B. 2012. Sistem Informasi Geografis. Fakultas Pertanian Universitas Bengkulu. Bengkulu.

Umar., Iswandi, Widiatmaka, Pramudya B, dan Barus B. 2017. Evaluasi Kesesuaian Lahan Untuk Kawasan Permukiman dengan Metode Multi Criteria Evaluation di Kota
Bengkulu. Jurnal Pengelolaan Sumberdaya Lam dan Lingkungan. Vol. 7 No. 2 (Agustus 2017). Hal. $148-154$

Undang Undang Nomor 29 Tahun 2009 tentang Perubahan Atas Undang Undang Nomor 15 Tahun 1997 tentang Ketransmigrasian.

Utubulang, Nofredy J., Veronica A. Kumumur, dan Ingrid L. Moniaga. 2015. Analisis Kesesuaian Lahan Permukiman di Kawasan Sekitar Koridor Ring Road I Manado. Sabua. Vol. 7 No. 1. Hal. 447-455 